\title{
BRAND VALUATION MODEL
}

\author{
Romualdas Ginevičius, Darius Gudačiauskas \\ Enterprise economics and business management department, Vilnius Gediminas Technical University, \\ Sauletekio al. 11, LT - 10223 Vilnius, Lithuania. \\ E-mail:romualdas.ginevicius@adm.vtu.lt; gudaciauskas@ldr.lt \\ Received 27 February 2004; accepted 29 April 2004
}

\begin{abstract}
Brand valuation technique is a core problem in a company value creation process. It has been done a lot of researches on the issue since brand valuation hit the headlines in 1988. The main task in brand valuation is to distinguish brand earnings from the earnings attributable to another assets: patents, intellectual property, and tangible assets. This seems to be an undisputable must, but not the only task for brand valuator. Another task is to estimate probability that the brand will generate these earnings in the future. Aim of our article is to propose brand earnings calculation, brand index calculation and brand risk assessment models, which are the results of the final doctoral dissertation. We believe that we have developed an ideal brand valuation model for emerging markets with low share liquidity.
\end{abstract}

Keywords: brand value, brand value index, brand equity, brand earnings, and brand valuation

\section{Introduction}

Fundamental changes initiated by globalisation, new technologies, intensive competition, volatile consumer demand, changes of economic and political systems become new challenges for business companies. These evolutionary changes encourage companies to learn faster, react adequately, adapt actively to the environment and change themselves. This situation prompted business companies to look for sources of competitive edge distinguishing the companies from their closest competitors.

The end of the last century observed a significant change in the company value components. Not long ago, shareholders' equity was mainly described by tangible assets, such as buildings, land, equipment and inventories. Recently, intangible assets, such as brand names, patents, intellectual property, became prevailing elements of the company value. The difference between the market capitalisation and net shareholders' equity became particularly significant. For instance, the research made in the United Kingdom in 1998 showed that only 28 per cent of the market capitalisation can be explained by net book value, and the remaining 78 per cent were attributable to other intangible assets, the major part of which, as a rule, is represented by brand value [1]. Thus, such proportion of the company value forces to look for ways how to evaluate the brand value created in the company as precise as possible.

As calculations of brand values are based on the projection of future profitability and are dependent on a lot of assumptions related to consumption and cost structure, one can state that an absolute brand value does not exist in practice. While addressing the problem of evaluation of the brand financial value, we had to solve a number of problems: reliability of assumptions, risk and separability (how to separate beer from Švyturys brand). How difficult so ever the process of measuring the brand financial value is, thanks to our research the measurement of the brand financial value and application thereof in the industry of consumer commodities became possible in Lithuania as well.

\section{Scientific problem}

A brand is a psychological concept, measuring of the economic value of which is one of the most interesting 
tasks for economic and management sciences and business practise. Although this problem has been investigated worldwide for several decades already, it is practically untouched in Lithuania. Until now no single measurement of brand economic value created in the company is made in Lithuania. The investigation of this scientific problem by employing the results of scientific research made in foreign countries presupposes creation of the measurement model for brand value adapted for the Lithuanian market, by addressing a lot of specific economic, psychological and management issues.

\section{Objective of the study}

To develop a model for measuring the brand economic value, which would allow for measuring the brand values created within the company in Lithuania.

\section{Tasks of the study}

The objective of the study was achieved by addressing the following tasks:

1. Disclosure of importance of the brand economic value in the activities of the company;

2. Analysis of the methodologies to measure the brand economic value used worldwide and disclosure of the main components of the brand valuation process;

3. Development of a measurement model for brand economic value in the Lithuanian environment by creating new methods, in order to:

a. Define earnings generated by intangible assets;

b. Calculate the brand value coefficient;

c. Calculate the size of the profit generated by the brand;

d. Calculate the discount rate of the cash flow generated by the brand;

e. Calculate the economic value of the brand.

4. By calculating the economic value of the cigarette brand.

\section{Methods of the study}

The basis for the methodology of the study consists of the principles of systemic analysis, in order to disclose the formation of the brand value. The methodology of the study is focused on investigation of the brand valuation methods as an object for scientific research, formation of the theory, and analysis in the environment of the contemporary market in Lithuania. The addressing of the objectives set by the study involved the knowledge from areas of finance, economics, statistics, mathematics, management, psychology, sociology and other sciences.
While performing the study, the following methods were employed:
a) Studying of archives;
b) Analytical analysis;
c) Systemic analysis;
d) Comparative analysis;
e) Conceptual simulation;
f) Quantitative consumer survey.

The following sources of theoretical and practical knowledge have been analysed and employed: scientific thesis defended in USA, periodic publications on the subject, review of quantitative and qualitative surveys made by the companies selling cigarettes, methodologies of scientific studies of the European Association of Sociological and Marketing Surveys, various publications on measurement of the company value and intangible assets, as well as publications on brand phenomenon.

\section{Academic novelty}

Implementation of the main objective - development of the model for calculation of brand economic value and its application in the Lithuanian market necessitated innovative solutions in order to ensure the theoretical justification of the model developed by the author and compliance thereof with main provisions of international brand valuation practice.

The academic novelty of the study is revealed at both theoretical and practical levels. First of all, the study presents a uniform terminology of Lithuanian definitions of the brand. In order to develop a model of measuring of brand economic value applicable in Lithuania, a number of solutions which are absolutely new from the scientific point of view were developed:

1. Methodology for calculation of brand equity;

2. Brand risk calculation methodology;

3. Brand value index calculation methodology.

The research covered the analysis and summary of studies on brand valuation and management, as well as the foreign experience of practical application of brand value. The results of the representative survey on cigarette consumers are of not less importance, and helped in revealing a psychological value of a brand.

\section{Brand value index calculation methodology}

Scope of the study and consumer survey using ,,inhall test" approach.

In order to define a consumer index of Brand $\mathrm{X}$ or, in other words, a probability that, given a specific price, a consumer will choose this alternative and not the other, a survey was carried out in Vilnius on $28-$ 
29 April 2004. Prior to the survey, a check questionnaire and a cigarette test questionnaire were developed. The survey was carried out in the form of a direct interview, using ,in-hall test" approach [2].

As questions in the survey were pre-formulated, this interview may be classified as a formalised interview.

During the survey 100 respondents were interviewed. The age of the respondents varies from 18 to 44 years, as the consumers of this age represent the major part $(86 \%)$ of smokers within the segment under survey. The age of fifty respondents was within 18 and 24 years, and the remaining fifty - from 25 to 44 years. The survey covered 70 men and 30 women, who smoke at least five cigarettes a day. The proportion of males and females in the survey corresponds to the composition of smokers in Lithuania by gender. Therefore, the study results are considered to be representative as they reflect the distribution of the active smokers by age and gender in the segment and in the market in the best way.

At the beginning of the survey the first questionnaire was presented to the respondents. This questionnaire included nine questions, and the respondents who had answered them, were invited to the further survey.

As at the beginning of the survey the questions and the entire procedure were planned in advance, so in order to get reliable answers, the first questionnaire contained fixed answers, allowing the respondent to choose one from two or more options. The advantage of such questions lies also in that the pre-formulated answers are easy to encode. The second questionnaire included not only questions with fixed answers but also open questions and requests to score cigarette quality.

In the beginning of the first questionnaire a gender of the respondents is determined, as $70 \%$ of men and $30 \%$ of women were interviewed, as mentioned above. In addition, it is important to find out the age of the respondent. If the respondent is under 18, the interview is terminated, as selling of cigarettes to persons of this age is restricted by law. As the objective set at the beginning of the survey was to interview persons under 44 years old, so in case the respondent is above this age limitation, the interview was terminated as well.

The questionnaire includes a question aimed at determining the area in which the respondent and his/ her family members are employed. If the occupation of the respondent or his/her family members is related to marketing, advertising, manufacturing and selling of tobacco products, market surveys and journalism, the interview is terminated, as the said areas may have an impact on the results of the survey [3].

Also, if it appears that the respondent does not smoke, the interview is terminated. As the objective set at the beginning of the survey was to interview persons who smoke at least five cigarettes a day and smoke the cigarettes of brand $\mathrm{X}$, i. e. the brand under survey, the respondents were asked to show a packet of cigarettes. If it appears that the respondent smokes fewer cigarettes or prefer cigarettes of other brands or currently has no packet of cigarettes of brand $\mathrm{X}$, which would clearly prove the answers of the respondents, the interview is terminated. It should be stressed the only those respondents who did not participate in a cigarette test during last six months were selected for the survey.

The persons who met the aforementioned criteria were invited to the further survey on cigarette brand.

The respondents who agreed to participate in the further survey were given questions from the second questionnaire. At the beginning the interviewer indicates the beginning of the interview and the gender of the respondent. Then introductory questions related to the age, smoking habits of the respondent and the preferred brands of cigarettes are presented. Also, they are asked to specify what cigarette brands the respondent smokes regularly during the month.

After answering to the introductory questions, the respondents were given to smoke cigarettes of three types. The first packet is presented with the identification of brand $\mathrm{X}$, the second bears no identification of brand $\mathrm{X}$, the third is marked with brand $\mathrm{Y}$ and the fourth bears brand $\mathrm{Z}$. Cigarettes with brand $\mathrm{Z}$ were not smoked, due to too big quantity of cigarettes smoked at the same time, which could distort the results of the survey. Therefore, the consumers described the preferences of this brand hypothetically. The testing procedure of the cigarettes was changed in such a way that all three types of cigarettes were tested in the first, second and third position the same number of times. Smoking of two cigarettes was separated by a break of about 10 minutes, and the respondents were allowed to drink some water.

The respondent who had smoked the first cigarette was asked to assess the cigarette quality in ten score scale, where „1“" means ,very poor quality“ and „10“ - ,very high quality". After a ten minutes break the respondent is offered a second cigarette, the quality of which he/ she assesses in ten score scale. Later, again after ten 
minutes, he/she is offered a third cigarette, the quality of which he/she also scores. Then the respondent is asked to assess the quality of cigarettes of one more brand Z. A difference of perceived quality between a brand and a product without a brand is one of the evidences about the existence of brand value, however, let us remind you that the major proof of its value is an ability to set a higher price than that one of analogous products or to gain higher preferences of the consumers given the same price.

After the completion of the cigarette test, there are four cards with the names of cigarettes placed in front of the respondent, followed by piles of eight price sheets $(3,75 ; 3,85 ; 3,95 ; 4,05 ; 4,15 ; 4,25 ; 4,35 ; 4,45)$. The price sheets are placed in ascending order, i. e. the lowest price on the top, and the highest price at the bottom. The respondent is asked to imagine a situation that currently only these cigarette brands are available in the shop, and the price is the same for all of them - LTL 3,75. Then the interviewer asks which brand the respondent will prefer. After the respondent names the type of cigarettes, the interviewer marks the first choice with „1“. In case the respondent does not indicate anything, general questions about education, income of the respondent are asked and the interview is terminated.

If the respondent indicates a type of cigarettes, the survey is continued. The interviewer raises the price of the chosen cigarettes by ten cents, i. e. takes one price sheet away and asks what brand the respondent will prefer this time. This test is continued until the respondent chooses some type eight times or answers that he made no choice. After the respondent answers the questions, he/she is asked to indicate his/her education and income. Then the interview is completed and the interviewer notes the end, duration and date of the interview.

The maximum bias of the survey is calculated according to the formula [4]:

$$
\begin{gathered}
S=\sqrt{\frac{P^{*} Q}{n}} * 100, \\
Q+P=1,
\end{gathered}
$$

where: $S$ - maximum statistical bias; $P$ - probability that the variable will take one value; $Q$ - probability that the variable will take another value; $n$ - scope of the survey.

Maximum calculated statistical bias of the survey date is $-9,8 \%$.

\begin{tabular}{|l|c|c|c|c|}
\hline & Brand X & $\begin{array}{c}\text { Without } \\
\text { brand }\end{array}$ & Brand Y & Brand Z \\
\hline $\begin{array}{l}\text { Average assessment in } \\
10 \text { scores ( - very } \\
\text { poor; } 10 \text { - very good) }\end{array}$ & 8,13 & 6,58 & 5,75 & 6 \\
\hline $1-3$ scores & $0 \%$ & $7,1 \%$ & $21,8 \%$ & $10,8 \%$ \\
\hline 4-6 scores & $11 \%$ & $36,7 \%$ & $29,9 \%$ & $45,9 \%$ \\
\hline $7-10$ scores & $89 \%$ & $56,2 \%$ & $48,3 \%$ & $43,3 \%$ \\
\hline
\end{tabular}

Fig 1. Cigarette brand quality perception

Differences between brand $\mathrm{X}$ and other cigarettes perception are statistically material $(\mathrm{p}=0.05)$.

Consumers scored the quality of the cigarettes with the identifying brand by $24 \%$ higher than the quality of the same product without the identifying brand (Fig 1). If the product did not bear a well known brand X, its quality would be perceived equally as the quality of the competing brands, which would mean that a probability that the consumer will try another brand or even exchange it for the competing brand is very high. Nevertheless, we can not refer only to the quality perception as the main feature of product preference. It is very important to define the scope of the preference when the consumer is really to buy the product. Thus, the price in making the decision to buy is a very relevant factor [5].

Analysis of preference ranks and interpretation of the findings.

The summarised findings of the preference analysis are presented in the figures below.

\begin{tabular}{|l|c|c|c|}
\hline \multicolumn{4}{|c|}{ Cigarettes without the identifying brand } \\
\hline Choice & $\begin{array}{c}\text { If the price is } \\
\text { LTL 3,75 }\end{array}$ & $\begin{array}{l}\text { Will not } \\
\text { buy at all }\end{array}$ & $\begin{array}{c}\text { Outstanding } \\
\text { respondents }\end{array}$ \\
\hline 1 & 12 & & 88 \\
\hline 2 & 4 & 0 & 84 \\
\hline 3 & 6 & 1 & 77 \\
\hline 4 & 9 & 1 & 67 \\
\hline 5 & 2 & 2 & 63 \\
\hline 6 & 5 & 3 & 55 \\
\hline 7 & 6 & 0 & 49 \\
\hline 8 & 0 & 1 & 48 \\
\hline 9 & 2 & 2 & 27 \\
\hline 10 & 2 & 3 & 21 \\
\hline 11 & 1 & 0 & 17 \\
\hline 12 & 0 & 0 & 15 \\
\hline 13 & 0 & 0 & 14 \\
\hline 14 & 1 & 0 & 6 \\
\hline 15 & & 1 & 5 \\
\hline 16 & & & 5 \\
\hline 17 & & & 2 \\
\hline 18 & & & \\
\hline 19 & & & \\
\hline 20 & & & \\
\hline 21 & & & \\
\hline
\end{tabular}

Fig 2. Cigarette preference in relation to the price 
Cigarettes without the identifying brand at a current market price of LTL 3,75 would be the first priority for twelve respondents (Fig 2). Thus, we can see that out of one hundred respondents the preference for the product without the identifying brand in relation to other brands would be twelve per cent. This is the number of respondents whose first choice would be this product. The remaining $88 \%$ of preferences are divided among other brands under survey.

Cigarettes brand $\mathrm{X}$ at a current market price of LTL 3,75 would be the first priority for eighty-four respondents (Fig 3). Thus, we can see that out of one hundred respondents the preference for the product with brand $\mathrm{X}$ in relation to other brands would be eighty-four per cent. This is the number of respondents whose first choice would be this product. The remaining $16 \%$ of preferences are divided among other brands under survey.

Cigarettes brand $\mathrm{Y}$ at a current market price of LTL 3,75 would be the first priority only for one respondent (Fig 4). Thus, we can see that out of one hundred respondents the preference for the product with brand $\mathrm{Y}$ in relation to other brands would be one per cent. This is the number of respondents whose first choice would be this product. The remaining $99 \%$ of preferences are divided among other brands under survey.

Cigarettes brand $\mathrm{Z}$ at a current market price of LTL 3,75 would be the first priority only for three respondents (Fig 5). Thus, we can see that out of one hundred respondents the preference for the product

\begin{tabular}{|l|c|c|c|c|c|c|c|c|}
\hline \multicolumn{7}{|c|}{ Cigarettes with brand X } \\
\hline \multirow{2}{*}{ Choice } & \multicolumn{7}{|c|}{ Price, in LTL } \\
\hline & $\mathbf{3 , 7 5}$ & $\mathbf{3 , 8 5}$ & $\mathbf{3 , 9 5}$ & $\mathbf{4 , 0 5}$ & $\mathbf{4 , 1 5}$ & $\mathbf{4 , 2 5}$ & $\mathbf{4 , 3 5}$ & $\mathbf{4 , 4 5}$ \\
\hline 1 & 84 & & & & & & & \\
\hline 2 & 3 & 68 & & & & & & \\
\hline 3 & 1 & 7 & 53 & & & & & \\
\hline 4 & & 3 & 8 & 32 & & & & \\
\hline 5 & & & 4 & 3 & 25 & & & \\
\hline 6 & & & 2 & 7 & 0 & 19 & & \\
\hline 7 & & & 3 & 8 & 2 & 0 & 18 & \\
\hline 8 & & & & 2 & 12 & 2 & 0 & 18 \\
\hline 9 & & & & 3 & 3 & 5 & 0 & 0 \\
\hline 10 & & & & 1 & 3 & 2 & 5 & 0 \\
\hline 11 & & & & & 0 & 4 & 0 & 4 \\
\hline 12 & & & & & 3 & 2 & 5 & 1 \\
\hline 13 & & & & & & 2 & 3 & 1 \\
\hline 14 & & & & & & 1 & 2 & 5 \\
\hline 15 & & & & & & 1 & 0 & 0 \\
\hline 16 & & & & & & 1 & 0 & 0 \\
\hline 17 & & & & & & & 3 & 0 \\
\hline 18 & & & & & & & 1 & 2 \\
\hline 19 & & & & & & & 1 & 1 \\
\hline 20 & & & & & & & & 1 \\
\hline 21 & & & & & & & & \\
\hline
\end{tabular}

Fig 3. Cigarette brand $\mathrm{X}$ preference in relation to the price

\begin{tabular}{|l|c|c|c|c|c|c|c|c|}
\hline \multicolumn{7}{|c|}{ Cigarettes brand Y } \\
\hline \multirow{2}{*}{ Choice } & \multicolumn{7}{|c|}{ Price, in LTL } \\
\hline & $\mathbf{3 , 7 5}$ & $\mathbf{3 , 8 5}$ & $\mathbf{3 , 9 5}$ & $\mathbf{4 , 0 5}$ & $\mathbf{4 , 1 5}$ & $\mathbf{4 , 2 5}$ & $\mathbf{4 , 3 5}$ & $\mathbf{4 , 4 5}$ \\
\hline 1 & 1 & & & & & & & \\
\hline 2 & 4 & & & & & & & \\
\hline 3 & 6 & 1 & & & & & & \\
\hline 4 & 7 & 2 & & & & & & \\
\hline 5 & 3 & 7 & 1 & & & & & \\
\hline 6 & 2 & 6 & 6 & & & & & \\
\hline 7 & 3 & 3 & 1 & 1 & & & & \\
\hline 8 & 0 & 2 & 1 & 2 & & & & \\
\hline 9 & 0 & 1 & 4 & 1 & 1 & & & \\
\hline 10 & 1 & 0 & 1 & 1 & 1 & & & \\
\hline 11 & 1 & 1 & 2 & 0 & 0 & 1 & & \\
\hline 12 & & 1 & 1 & 0 & 0 & 1 & & \\
\hline 13 & & & 1 & 2 & 1 & 0 & 1 & \\
\hline 14 & & & & 1 & 0 & 0 & & \\
\hline 15 & & & & 0 & 1 & 0 & & 1 \\
\hline 16 & & & & 1 & 1 & 0 & & \\
\hline 17 & & & & & 1 & 0 & & \\
\hline 18 & & & & & & 1 & & \\
\hline 19 & & & & & & 1 & & \\
\hline 20 & & & & & & & & \\
\hline 21 & & & & & & & & \\
\hline
\end{tabular}

Fig 4. Cigarette brand $Y$ preference in relation to the price

with brand $\mathrm{Z}$ in relation to other brands would be three per cent. This is the number of respondents whose first choice would be this product. The remaining $97 \%$ of preferences are divided among other brands under survey. Let us remind you that the other prices were presented with the aim to distract the consumer from real service prices and avoid simulation of responses based on the reality.

\begin{tabular}{|l|c|c|c|c|c|c|c|c|}
\hline \multicolumn{7}{|c|}{ Cigarettes brand Z } \\
\hline \multirow{2}{*}{ Choice } & \multicolumn{7}{|c|}{ Price, in LTL } \\
\hline & 3,75 & 3,85 & 3,95 & 4,05 & 4,15 & 4,25 & 4,35 & 4,45 \\
\hline 1 & 3 & & & & & & & \\
\hline 2 & 8 & 1 & & & & & & \\
\hline 3 & 9 & 0 & & & & & & \\
\hline 4 & 10 & 5 & & & & & & \\
\hline 5 & 5 & 14 & 1 & & & & & \\
\hline 6 & 3 & 5 & 5 & & & & & \\
\hline 7 & 3 & 2 & 5 & & & & & \\
\hline 8 & & 2 & 6 & 1 & & & & \\
\hline 9 & & & 3 & 6 & & & & \\
\hline 10 & & & 0 & 3 & 4 & & & \\
\hline 11 & & & 1 & 2 & 4 & 1 & & \\
\hline 12 & & & & 2 & 0 & 1 & & \\
\hline 13 & & & & 0 & 0 & 4 & & \\
\hline 14 & & & & 1 & 3 & 0 & 1 & \\
\hline 15 & & & & & 2 & 1 & 0 & \\
\hline 16 & & & & & 1 & 1 & 0 & \\
\hline 17 & & & & & & 1 & 0 & \\
\hline 18 & & & & & & & 1 & \\
\hline 19 & & & & & & & 0 & \\
\hline 20 & & & & & & & 1 & \\
\hline 21 & & & & & & & & 1 \\
\hline
\end{tabular}

Fig 5. Cigarette brand $\mathrm{Z}$ preference in relation to the price 


\begin{tabular}{|c|c|c|c|c|c|}
\hline & 1997 & 1998 & 1999 & 2000 & 2001 \\
\hline Total sales of cigarettes & 6548 & 7484 & 8093 & 7517 & 8046 \\
\hline Sales of brand $X$ & 666 & 811 & 808 & 620 & 698 \\
\hline Total sales & 55509 & 79001 & 84890 & 66508 & 75562 \\
\hline Taxes & 10443 & 14983 & 20205 & 18388 & 22087 \\
\hline Discounts & 93 & & & 1619 & 2862 \\
\hline \multicolumn{6}{|l|}{ Production costs } \\
\hline SVC & 23148 & 24645 & 23977 & 19662 & 19745 \\
\hline FME & 1885 & 2481 & 2222 & 2993 & 3014 \\
\hline Distribution costs & 111 & 129 & 178 & 171 & 169 \\
\hline Selling costs & 421 & 609 & 734 & 890 & 854 \\
\hline Indirect marketing expenses & 104 & 356 & 319 & 605 & 963 \\
\hline Market research & 21 & 66 & 217 & 90 & 77 \\
\hline Marketing & & & 137 & 313 & 321 \\
\hline Direct marketing expenses & 2516 & 2297 & 2758 & 2468 & 2691 \\
\hline Depreciation of tangible assets & 664 & 1306 & 1422 & 1233 & 1781 \\
\hline Overhead & 1537 & 2511 & 2953 & 2384 & 4105 \\
\hline Tangible assets used in production & 232 & 69 & 109 & 234 & 77 \\
\hline Working capital & 354 & 377 & 708 & 132 & 135 \\
\hline
\end{tabular}

Fig 6. Initial data for measurement of brand financial value

\begin{tabular}{|c|l|}
\hline \multirow{2}{*}{$\begin{array}{c}\text { Less operating } \\
\text { costs: }\end{array}$} & Income after taxes and discounts: \\
\cline { 2 - 2 } & Production costs \\
\cline { 2 - 3 } & Distribution and selling costs \\
\cline { 2 - 3 } $\begin{array}{c}\text { Less funding } \\
\text { costs: }\end{array}$ & Depreciation costs of tangible assets \\
\cline { 2 - 2 } Result: & Alternative capital costs \\
\hline Earnings generated by intangible assets \\
\hline
\end{tabular}

Fig 7. Intangible assets earnings calculation model

\section{Brand economic value calculation}

Initial data required for measurement of brand financial value are presented in the Fig 6 bellow:

In first stage earnings generated by intangible assets are calculated [6] (Fig 7).

In the second stage we calculate a brand value index (Fig 8). The results produced by ,in-hall test “ research are presented in the Fig 9.

We use the value index formula to calculate the brand value index (Fig 10):

$$
P \check{Z} V K=85,70 \% \text {, }
$$

where: $P \check{Z} V K$ - brand value coefficient.

In the third stage earnings generated by brand $\mathrm{X}$ are calculated:

$$
P \check{Z} P=N T P \times P \check{Z} V K
$$

where: $P \check{Z} P$ - earnings generated by the brand; $N T P$ - earning generated by intangible assets; $P \check{Z} V K$ - brand value coefficient.

In the fourth stage a discount rate is calculated by using the equity approach.

Initially, weights of the equity elements are calculated, taking into consideration the market share:

$$
\check{Z} S=\check{Z} \times R D,
$$

where: $\check{Z} S$ - recognition weight; $\check{Z}$ - recognition; $R D$ - market share.

$$
P S=P \times R D,
$$

where: $P S$ - preference weight; $P$ - preference; $R D$ - market share.

$$
L S=L \times R D,
$$




\begin{tabular}{|c|c|c|c|c|c|}
\hline & 1997 & 1998 & 1999 & 2000 & 2001 \\
\hline Total sales & 55509 & 79001 & 84890 & 66508 & 75562 \\
\hline Taxes & 10443 & 14983 & 20205 & 18388 & 22087 \\
\hline Discounts & 93 & & & 1619 & 2862 \\
\hline Income after taxes and discounts & 44973 & 64018 & 64685 & 46501 & 50613 \\
\hline Production costs & 25033 & 27126 & 26199 & 22655 & 22759 \\
\hline SVC & 23148 & 24645 & 23977 & 19662 & 19745 \\
\hline FME & 1885 & 2481 & 2222 & 2993 & 3014 \\
\hline Distribution and selling costs & 3173 & 3457 & 4343 & 4237 & 5075 \\
\hline Distribution & 111 & 129 & 178 & 171 & 169 \\
\hline Selling & 421 & 609 & 734 & 890 & 854 \\
\hline Indirect marketing & 104 & 356 & 319 & 605 & 963 \\
\hline Market research & 21 & 66 & 217 & 90 & 77 \\
\hline Marketing & & & 137 & 313 & 321 \\
\hline Direct marketing & 2516 & 2297 & 2758 & 2468 & 2691 \\
\hline Depreciation and management costs & 2201 & 3817 & 4375 & 3617 & 5886 \\
\hline Depreciation of tangible assets & 664 & 1306 & 1422 & 1233 & 1781 \\
\hline Overhead & 1537 & 2511 & 2953 & 2384 & 4105 \\
\hline Alternative capital costs $(15 \%)^{*}$ & 87,90 & 66,90 & 122,55 & 54,90 & 31,80 \\
\hline Tangible assets & 232 & 69 & 109 & 234 & 77 \\
\hline Salaries and wages & 354 & 377 & 708 & 132 & 135 \\
\hline Earnings generated by intangible assets & 14478,10 & 29551,10 & 29645,45 & 15937,10 & 16861,20 \\
\hline
\end{tabular}

* We assume that alternative capital costs make up $15 \%$, i. e. the owners of the company could expect such a return on equity if investments are made into another business.

Fig 8. Intangible assets earnings calculation

\begin{tabular}{|l|c|}
\hline \multicolumn{1}{|c|}{ Parameter } & Value \\
\hline Preference without brand & 12 \\
\hline Preference with brand X & 84 \\
\hline Market price (LTL) & 3,75 \\
\hline
\end{tabular}

Fig 9. ,in-hall test“ research results

where: $L S$ - loyalty weight; $L$-loyalty; $R D$ - market share.

Initial data are presented in the Fig 11 and Fig 12 sources are described bellow the figure.

These data are obtained using an approach of different quantitative analysis. Bellow we present a reference to the analysis and explanation of the parameter defined [7]:

\begin{tabular}{|l|c|c|c|}
\hline \multirow{2}{*}{ Parameters } & \multicolumn{3}{|c|}{ Brands } \\
\cline { 2 - 4 } & $\mathrm{X}$ & $\mathrm{Y}$ & $\mathrm{Z}$ \\
\hline Recognition & 61 & 25 & 32 \\
\hline Preference & 68 & 20 & 12 \\
\hline Loyalty & 47 & 51 & 49 \\
\hline & & & \\
\hline Market share & 13,4 & 3,40 & 1,30 \\
\hline
\end{tabular}

Fig 11. Brand equity components

1. Recognition. Equity calculation employs spontaneous recognition of the brand being analysed, it has been taken from the quantitative consumer survey of 2001 commissioned by the company;

\begin{tabular}{|l|c|c|c|c|c|}
\hline & 1997 & 1998 & 1999 & 2000 & 2001 \\
\hline Earnings generated by intangible assets (LTL) & 14478,10 & 29551,10 & 29645,45 & 15937,10 & 16861,20 \\
\hline Brand X value coefficient (\%) & 85,70 & 85,70 & 85,70 & 85,70 & 85,70 \\
\hline Brand X earnings (LTL) & $\mathbf{1 2 4 0 7 , 7 3}$ & $\mathbf{2 5 3 2 5 , 2 9}$ & $\mathbf{2 5 4 0 6 , 1 5}$ & $\mathbf{1 3 6 5 8 , 0 9}$ & $\mathbf{1 4 4 5 0 , 0 5}$ \\
\hline
\end{tabular}

Fig 10. Brand $X$ earnings calculation 
2. Brand preference. Brand preference is a function of a number of qualitative and quantitative parameters. Nevertheless, its essence lies in that consumers, being aware of the aforementioned parameters, choose one or another brand. Therefore, preference may be calculated as a percentage of consumers who have chosen one or another brand within the same segment. The data of the quantitative consumer survey of 2001 commissioned by the company are used;

3. Loyalty. The essence of this parameter is in that in spite of active efforts of competitors to offer analogous or even more advantaged from the functionality point of view products, consumers continue using the same brand. Therefore, the loyalty may be calculated as a percentage of consumers who did not change their brand over the last 12 months. The data of the quantitative consumer survey of 2001 commissioned by the company are used;

4. Market share. It is a ratio of sales volumes of the cigarette brands being analysed to the entire market of legally sold cigarettes. The data of the quantitative market audit of 2001 commissioned by the company are used.

By applying formulas 5, 6, 7, we calculate weighted equity components. The results are presented in the Fig 12.

\begin{tabular}{|l|c|c|c|}
\hline \multirow{2}{*}{ Parameters } & \multicolumn{3}{|c|}{ Brands } \\
\cline { 2 - 4 } & $\mathrm{X}$ & $\mathrm{Y}$ & $\mathrm{Z}$ \\
\hline Recognition & 817,4 & 85 & 41,60 \\
\hline Preference & 911,2 & 68 & 15,6 \\
\hline Loyalty & 629,8 & 173,4 & 63,7 \\
\hline
\end{tabular}

Fig 12. Weighted brand equity components

After having calculated equity weights, we can calculate brand $\mathrm{X}$ equity:

$$
V V_{X}=84,0574 \% \text {, }
$$

where: $V V_{X}-$ brand $\mathrm{X}$ equity.

Brand equity index may vary in the range from 0 to 100 and, depending on the market, may produce a risk premium from 0 to 100 percentage points, see Exhibit 1 , if compared with the risk coefficient "beta“ of the same industry. A risk premium for an individual business sector may be obtained from the stock exchange or banks which assess credits risk of individual business sectors [8].

50 points indicate that the brand in the sector being analysed bears 50 per cent lower risk, if compared with investment risk. Thus, brand risk coefficient Beta will be equal to the product of investment risk and brand risk coefficient. It means that while calculating a discount rate, brand risk premium will be added to

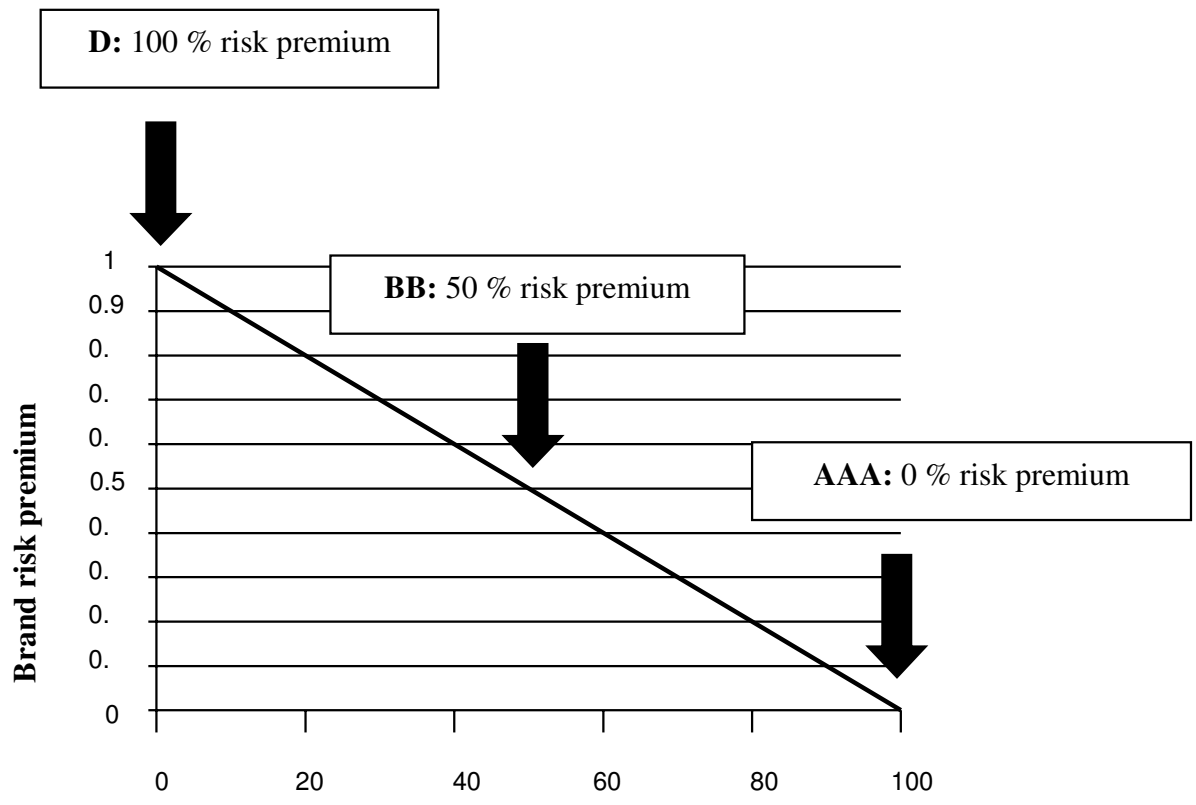

Brand equity 0 - $100 \%$

Adapted Brand risk premium model 
the average market risk rate. It should be noted that in such a way the risk of brand popularity decrease is eliminated [9].

Based on the suggested approach, the equity equal to 84,0574 corresponds to brand risk premium of 0,15 .

Discount rate is calculated in the following way:

Discount rate $=(\beta$ rand $\beta$ eta adjusted equity cost $) \mathrm{x}$ (equity funding share) $+\left(\right.$ debt $\left.\operatorname{cost}^{*}\right) \times$ (debt funding share).

* Debt cost is equal to interest rate payable by the company to the bank. In our case the company pays the annual interest of $5 \%$. Calculations use the following funding proportions: $70 \%$ equity and $30 \%$ debt funding share in the company.

Brand $\beta$ eta adjusted equity cost is calculated in accordance with the adapted Brand Finance formula:

Brand $\beta$ eta adjusted equity cost $=$ (equity risk premium $)$ + (equity risk premium) $\mathrm{x}$ (ßrandßeta).
First, we calculate Brand $\beta$ eta adjusted equity cost using formula (9):

Brand $\beta$ eta adjusted equity cost $=0,09+(0,09 \times 0,15)=$ 0,1035 .

According to the data of „Hansa Markets“ experts, a nonrisky borrowing rate is $6 \%$ and $3 \%$ is maximum liquidity premium, therefore, equity risk premium is $9 \%$, $\beta$ randßeta value according to the suggested model is 0,15 .

After having calculated ßeta adjusted equity costs according to formula (9), we can calculate a discount rate:

Discount rate $=(0,1035 \times 0,7)+(0,05 \times 0,3)=0,0874$.

In the first stage we calculate the brand financial value. To this end, firstly, we calculate a present value of the future cash flow using Gordon Growth model [10].

\begin{tabular}{|c|c|c|c|c|c|}
\hline & 1997 & 1998 & 1999 & 2000 & 2001 \\
\hline Total sales & 55509 & 79001 & 84890 & 66508 & 75562 \\
\hline Taxes & 10443 & 14983 & 20205 & 18388 & 22087 \\
\hline Discounts & 93 & & & 1619 & 2862 \\
\hline Income after taxes and discounts & 44973 & 64018 & 64685 & 46501 & 50613 \\
\hline Productions costs & 25033 & 27126 & 26199 & 22655 & 22759 \\
\hline SVC & 23148 & 24645 & 23977 & 19662 & 19745 \\
\hline FME & 1885 & 2481 & 2222 & 2993 & 3014 \\
\hline Distribution and selling costs & 3173 & 3457 & 4343 & 4237 & 5075 \\
\hline Distribution & 111 & 129 & 178 & 171 & 169 \\
\hline Selling & 421 & 609 & 734 & 890 & 854 \\
\hline Indirect marketing & 104 & 356 & 319 & 605 & 963 \\
\hline Market research & 21 & 66 & 217 & 90 & 77 \\
\hline Marketing & & & 137 & 313 & 321 \\
\hline Direct marketing & 2516 & 2297 & 2758 & 2468 & 2691 \\
\hline Depreciation and management costs & 2201 & 3817 & 4375 & 3617 & 5886 \\
\hline Depreciation of tangible assets & 664 & 1306 & 1422 & 1233 & 1781 \\
\hline Overheads & 1537 & 2511 & 2953 & 2384 & 4105 \\
\hline Alternative capital costs $(15 \%)$ & 87,90 & 66,90 & 122,55 & 54,90 & $\mathbf{3 1 , 8 0}$ \\
\hline Tangible assets & 232 & 69 & 109 & 234 & 77 \\
\hline Salaries and wages & 354 & 377 & 708 & 132 & 135 \\
\hline Earnings generated by & 14478,10 & 29551,10 & 29645,45 & 15937,10 & 16861,20 \\
\hline \multicolumn{6}{|l|}{ Intangible assets } \\
\hline Brand value coefficient & $\mathbf{8 5 , 7 0} \%$ & $\mathbf{8 5 , 7 0 \%}$ & $\mathbf{8 5 , 7 0 \%}$ & $\mathbf{8 5 , 7 0 \%}$ & $\mathbf{8 5 , 7 0 \%}$ \\
\hline Brand $\mathrm{X}$ earnings & 12407,73 & 25325,29 & 25406,15 & 13658,09 & 14450,05 \\
\hline \multicolumn{6}{|l|}{ Discount rate $(8,74 \%)$} \\
\hline Discount factor & 1,0874 & 1,1824 & 1,2857 & 1,3981 & 1,5203 \\
\hline Discounted brand cash flow & 11410,4561 & 21418,5470 & 19760,5585 & 9769,0365 & $\mathbf{9 5 0 4 , 7 3 5 9}$ \\
\hline Present value of the brand cash flow over five years & 71863,3340 & & & & \\
\hline \multicolumn{6}{|l|}{ Growth $(0 \%)$} \\
\hline Brand value beyond the assessed period & 165332,3799 & & & & \\
\hline Brand value & 237195,7139 & & & & \\
\hline
\end{tabular}

Fig 13. Value of Brand $X$ 


$$
P V=\frac{1 \text { year } P S}{1+D N}+\frac{2 \text { years } P S}{(1+D N)^{2}}+\ldots+\frac{5 \text { years } P S}{(1+D N)^{5}},
$$

where: $P V$ - present value of the cash flow; $P S$ cash flow; $D N$ - discount rate.

Then we calculate the value beyond the analysed period, subject to $0 \%$ growth:

$$
V=\frac{5 \text { years } \text { PZearnings }}{D N \pm \text { growth }},
$$

where: $V$-value for the analysed period;

5 years PZearnings - brand $\mathrm{X}$ earnings over 5 years; $D N$ - discount rate.

Then brand value is calculated:

$$
P Z V=P V+V,
$$

where: $P Z V$ - brand value; $V$ - value for the analysed period; $P V$ - present value of the cash flow.

The results are provided in the Fig 13.

\section{Conclusion}

1. Among all practically used discounted cash flow models described in various publications, the most precise and universally accepted models are the brand economic value measurement models of the companies „Interbrand“ and „Brand finance“. Both approaches are developed to assess mainly international brands in well developed Western markets, where a company value is determined by stock markets. The definite disadvantage of these approaches is that they require particularly high costs to survey the behaviour of consumers, and they also are very much dependent on the market value of stocks. The stock market is not yet developed in Lithuania, and the liquidity of the stocks of the listed companies is low. Therefore, there is a need to develop a brand value measuring model applicable to the companies in Lithuania and other CEE countries. A very important criterion is that this approach could be also applicable to medium enterprises, not only to large ones. It should be noted that the algorithm of measuring the value of intangible assets of "Interbrand" is fully applicable for the Lithuanian environment, and having adapted brand risk Brand beta model of „Brand Finance“, it is possible to determine a brand risk premium for a brand of a Lithuanian company.
2. After having analysed the global practice of brand economic value measurement, a brand value measurement model was also developed in Lithuania; this model is ideal for application in Lithuania and other markets characterised by a low liquidity in the stock market. The suggested brand valuation model can be attached to complex discounted cash flow approaches. The advantage of this valuation model, if compared with other similar models, is a possibility to calculate earnings generated by intangible assets, with the view of demand factors, to calculate brand equity value and, having assessed the brand related risk, to calculate the brand value. It should be emphasised that the suggested model not only puts together certain elements of brand valuation methods, but also presents a new approach towards the solution of the existing problems of brand economy and management.

3. The analysis served as a prerequisite for development of brand value index calculation methodology which is based on determination of brand preference strength, calculation of brand price premium and calculation of brand value index. The survey was carried out by using ,inhall test" approach, which can be classified as one type of an investigative interview. It should be noted that the analysis of data obtained during the consumer survey is a complex one, the data were collected by using product price reconciliation technique, it is sufficient to present options of brands and prices for the respondents, which they have to consider prior to making a purchase decision. These options were demonstrated „live“ or using their photos. Respondents were informed orally what was requested from them. The survey covered 100 respondents within the age range from 18 to 40 years, as the consumers of this age represent the major part of smokers within the segment under survey. The age of fifty respondents was within 18 and 24 years, and the remaining fifty - from 25 to 44 years. The survey covered 70 men and 30 women, who smoke at least five cigarettes a day.

4. After the completion of ,in-hall" test and having processed the survey results, by using the preference rank analysis, the following findings were made:

a. Consumers evaluated the quality of cigarettes with the identifying brand by $24 \%$ higher than that of the same product without the identifying brand. 
b. Given the same selling price (the price represented a retail price of cigarettes prevailing in sale outlets) the cigarettes with the identifying brand would be preferred by $84 \%$ of consumers, and the cigarettes without the identifying brand would be preferred by only $12 \%$ of consumers. This can be explained by a psychological caution of the customer for cigarette quality (though he was assured that the quality is the same), an image or convenience for usage.

c. Having simulated hypothetic turnovers of the aforementioned brands, a brand value index was derived. This ratio indicates what part of the earnings generated by intangible assets can be allocated to the brand phenomenon. The brand value index in our survey is $85,7 \%$, i.e. this is the value which is generated by the brand.

5. Net cash flow generated by intangible assets of the company being analysed was calculated by using the model of „Interbrand“ for determination of the earnings of intangible assets. This cash flow multiplied by brand value index resulted in net cash flow of the brand over five years. This is the basis for brand value calculation.

6. While using a newly developed brand equity model, under which, depending on competitiveness of the market in which the branded product is sold, brand equity may be higher or lower and show the risk in the range from 0 to 100 percentage points, the $70 \%$ brand equity was calculated. This value of the brand being analysed makes up 84,0574 \% and according to the adapted brand risk determination model of „Brand Finance“ is equal to 0,15 of the equity cost coefficient. Given $70 \%$ of the equity funding share and $30 \%$ of the debt funding share in the company being analysed and by adjusting the equity cost, the brand risk is calculated as a discount rate of the future cash flow of the brand, which is $8,74 \%$.

7. Having calculated this discount rate, the value of the discounted net cash flow of the brand was calculated. To this end Gordon Growth model which is stipulated for calculation of a stock value served as a basis. In order to have as precise calculations as possible, the following limitations were considered: the operation of the company analysed is stable, growth rates are sustainable, the market in which the company is active is stable, the growth rate of the cash flow beyond the analysed period, is $0 \%$. The calculated present value of the cash flow of the brand over five years amounts to LTL 71,863,334, the brand value beyond the analysed period is LTL $165,332,380$. Thus, having summed it up, the economic value of brand $\mathrm{X}$ totals LTL $237,195,714$.

\section{References}

1. Roberts, K. Brand identity 2000. Advertising age. New York, 1999 November 22 ${ }^{\text {nd }}$, p. 50.

2. Rubinstein, H. Brand „first“ management. Journal of Marketing Management, 12, 1996, p. 269-280.

3. Smith, G. V. \& Russell, L. P. Valuation of Intellectual Property and Intangible Assets, 2nd ed. New York: John Wiley \& Sons, Inc., 1994.

4. Smith, G. V. Trademark valuation. John Wiley \&Sons, Inc., 1997, p. 95-99.

5. Schultz, Don E. Determining how brand communication works in the short and long terms. International Journal of Advertising, 1998, 17, p. 403-426.

6. Perrier, R. Interbrand. Brand Valuation. London: Permier books, 1997, p. 43-53.

7. Srivastava, R.K. \& Shocker, A.D. Brand equity: A perspective on its meaning and measurement. Cambridge, MA: Marketing Science Institute, report No 91124, 1991, p. 6-9.

8. Penrose, N. \& King, A. Evaluating Brands - US Experience and Practice. Brand Valuation Hutchinson Business Books. London, 1991, p. 143-153.

9. The valuation of Intangible Assets, 1992. A Report by Arthur Andersen. The Economist Intelligence Unit.

10. Stobart, P. Alternative Methods of Brand Valuation. Brand Valuation (ed. Murphy J.) Hutchinson Business Books, London, 1991, p. 24-32. 